\title{
Effect of unequal load of carbon xerogel in electrodes on the
}

\section{electrochemical performance of asymmetric supercapacitors}

E. G. Calvo ${ }^{1,2^{*}}$, F. Lufrano ${ }^{2 *}$, A. Arenillas ${ }^{1}$, A. Brigandi ${ }^{2}$, J.A. Menéndez ${ }^{1}$, P. Staiti ${ }^{2}$

${ }^{1}$ Instituto Nacional del Carbón CSIC, Apartado 73, 33080 Oviedo (Spain)

${ }^{2}$ Istituto di Tecnologie Avanzate per L'Energia “Nicola Giordano”, CNR-ITAE,

Via Salita S. Lucia 5, 98126 Messina (Italy)

\begin{abstract}
This paper investigates the electrochemical performance of asymmetric supercapacitors in an environmentally friendly aqueous electrolyte $\left(1.0 \mathrm{~mol} \mathrm{~L}^{-1}\right.$ sodium sulfate solution). The asymmetric configuration is based on the use of a highly porous carbon xerogel as active material in both the positive and negative electrodes, but the carbon xerogel loading in each electrode has been substantially modified. This configuration leads to an increase in the operational voltage window up to values of $1.8 \mathrm{~V}$ and consequently to a higher specific capacitance $\left(200 \mathrm{~F} \mathrm{~g} \mathrm{~g}^{-1}\right)$ and energy density $\left(\sim 25 \mathrm{Wh} \mathrm{kg}^{-1}\right)$. Four different mass ratios were employed (1, 1.5, 2 and 3) and the electrochemical response of the cells was evaluated by means of cyclic voltammetry, galvanostatic charge-discharge and impedance spectroscopy. The results demonstrate that the optimal carbon mass ratio in the electrodes is higher than 2.0 because in these conditions the devices are able to operate with a maximum cell voltage of $1.8 \mathrm{~V}$ and with a high electrical efficiency.
\end{abstract}

Keywords: Carbon xerogel electrodes; Asymmetric configuration; Electrode loading; High voltage; Aqueous electrolyte.

*Corresponding author. Tel.: +34985 1190 90; Fax: +34985297662

E-mail address: esthergc@incar.csic.es (E.G. Calvo); 1ufrano@itae.cnr.it (F. Lufrano)

\section{Introduction}

Supercapacitors (SCs) are electrochemical energy storage systems that are characterized by a high power rate and long cycle lifetime with a high coulombic efficiency, i.e., a high reversibility, and a low environmental impact [1-4]. With these properties, supercapacitors can be used as energy storage devices in a large number of applications, especially where a high 
power is needed for a short time, as in the case of hybrid electric vehicles (HEV) or emergency systems [1-4]. The main drawback of supercapacitors is their restricted energy density, which is much smaller than that supplied by other energy storage systems such as batteries or fuel cells (e.g. 4-8 $\mathrm{Wh} \mathrm{kg}^{-1}$ for a commercial symmetric supercapacitor, from 10 to $50 \mathrm{Wh} \mathrm{kg}^{-1}$ for an asymmetric SC based on a redox electrode and $>100 \mathrm{Wh} \mathrm{kg}^{-1}$ for Li-ion batteries [3]). Hence, a lot of the current research is directed towards developing more efficient supercapacitors in terms of energy density.

From the equation used to calculate the energy density $(E)$ of a supercapacitor:

$$
E=\frac{1}{2} C U^{2}
$$

where $C$ is the capacitance in Farads and $U$ the operating voltage, it can be seen that an efficient way to increase the energy density of supercapacitors would be to develop highly and suitably porous electrode materials to enhance the capacitance and/or to extend the voltage stability window. The latter can be defined as the voltage range within which neither the electrode material nor the electrolyte undergo decomposition.

The maximum voltage of aqueous-based supercapacitors is typically limited to $\sim 1.0 \mathrm{~V}$, due to the decomposition of water at $1.23 \mathrm{~V}$, whereas supercapacitors can be charged to a potential difference of $2.5 \mathrm{~V}$ or $>3.5 \mathrm{~V}$, when organic solutions and ionic liquids are used as electrolytes [5-7]. From the point of view of the voltage stability window of the electrolyte, it is evident that aqueous media are less favorable for this application. Nevertheless, this medium offers many advantages over the other two types of electrolytes including its higher conductivity, low cost, easy preparation and handling and low environmental impact [5-7]. In recent years, different strategies have been adopted to extend the working voltage of supercapacitors without having to replace aqueous solutions by other more expensive, complex and environmental unfriendly electrolytes. Some of these strategies have been aimed at the development of supercapacitors, based on aqueous solutions, which are composed of two electrode materials that are able to operate within different potential ranges, thereby enhancing the stability window of the supercapacitors. For example, some authors have developed asymmetric aqueous supercapacitors that exhibit a voltage stability window close to $2.0 \mathrm{~V}$ by employing a carbonaceous material as negative electrode and an active material with pseudo-capacitive properties as positive electrode (e.g. carbon xerogel (-) / $\mathrm{MnO}_{2}(+)$ [8]; activated carbon (-) / $\mathrm{MnO}_{2}(+)$ [9]; activated carbon (-) / $\mathrm{LiMn}_{2} \mathrm{O}_{4}(+)$ [10]; activated carbon (-) / activated carbon fibers-PANI (+) [11]; $\mathrm{MnO}_{2}-\mathrm{AC}(-) / \mathrm{Li}_{4} \mathrm{Mn}_{5} \mathrm{O}_{12}(+)$ [12] etc.). However, all of these proposals involve using two different active materials and, therefore, they lead to more expensive and less 
ecological supercapacitors than those composed solely of carbon materials. This has led several researchers to consider the possibility of developing asymmetric supercapacitors that employ the same nanoporous carbon in both electrodes but in unequal loads [13-16].

In 2012, some of the authors of the present paper published a study based on the preparation of an asymmetric supercapacitor that employed a highly porous carbon xerogel as active material with a mass ratio between the positive and negative electrode $\left(\mathrm{m}_{+} / \mathrm{m}_{\text {.) }}\right)$ of close to $2[16]$. In the present work, we have gone a step further and have modified the $\mathrm{m}_{+} / \mathrm{m}$. ratio with the aim of determining the optimal mass ratio that would result in a supercapacitor with a larger voltage window and a good electrochemical performance over a sizable number of charge-discharge cycles. For this purpose, four supercapacitors with different mass ratios between both electrodes $\left(\mathrm{m}_{+} / \mathrm{m}_{-}=1,1.5,2\right.$ and 3$)$ were assembled, using a micro-mesoporous carbon xerogel as active material in both electrodes and a sodium sulfate solution $\left(1.0 \mathrm{~mol} \mathrm{~L}^{-1}\right)$ as electrolyte. The performance of the cells was evaluated by means of different electrochemical techniques (cyclic voltammetry, galvanostatic charge/discharge and impedance spectroscopy).

\section{Experimental}

\subsection{Electrode material}

The active material selected for this study was a commercial carbon xerogel provided by Xerolutions (XER-HSA-09) (Oviedo - Spain). This carbon xerogel was obtained by means of polymerization reactions between resorcinol and formaldehyde monomers (the $\mathrm{pH}$ of the resorcinol/formaldehyde solution was 6.5), using microwave heating to favour the reactions [17, 18]. Once the microwave-induced synthesis had concluded, the material was subjected to an activation process using $\mathrm{CO}_{2}$ as activating agent at $1000{ }^{\circ} \mathrm{C}$ with a heating rate of $50{ }^{\circ} \mathrm{C} \mathrm{min}{ }^{-1}$ and this maximum temperature was kept for 2 hours, in order to ensure the development of microporosity in the sample [19]. The porosity of the carbon xerogel was characterized from the $\mathrm{N}_{2}$ adsorption-desorption isotherm at $-196{ }^{\circ} \mathrm{C}$ (Micromeritics Tristar 3020). Before the characterization, the sample was outgassed at $120{ }^{\circ} \mathrm{C}$ overnight under vacuum. The specific surface area $\left(\mathrm{S}_{\mathrm{BET}}\right)$ and micropore volume $\left(\mathrm{V}_{\text {micro }}\right)$ were calculated from the $\mathrm{N}_{2}$ adsorption isotherm by means of the Brunauer-Emmett-Teller and Dubinin-Raduskevich equations, respectively. The total pore volume $\left(\mathrm{V}_{\mathrm{p}}\right)$ was calculated from the $\mathrm{N}_{2}$ adsorbed at saturation point $\left(\mathrm{p} / \mathrm{p}^{\mathrm{o}}=0.99\right)$ and the mesopore volume $\left(\mathrm{V}_{\text {meso }}\right)$ was determined by subtraction $\left(\mathrm{V}_{\mathrm{p}}-\mathrm{V}_{\text {micro }}\right)$.

To investigate the chemical properties of the active material, it was subjected to elemental analysis tests. The amounts of $\mathrm{C}, \mathrm{N}$ and $\mathrm{H}$ were calculated using a LECO-CHNS-932 microanalyzer and the oxygen content was determined on a LECO-TF-900. The point of zero 
charge (PZC) was determined in order to facilitate the identification of the surface chemistry of the XER-HSA-09 carbon xerogel.

\subsection{The electrochemical response of asymmetric supercapacitors}

A series of square-shaped electrodes, with a surface of $4 \mathrm{~cm}^{2}$ and a thickness of between 100$250 \mu \mathrm{m}$, were prepared by mixing a slurry of carbon xerogel, graphite fibers, polyvinilidene fluoride (PVDF) in an organic solvent (N,N-dimethylacetamide). The mass ratio of the solid materials was fixed at 80:10:10. Once the composite electrodes were obtained, a drying step followed by a heat treatment at $160{ }^{\circ} \mathrm{C}$ was carried out in order to improve the mechanical strength of the final electrodes. Four different ratios of carbon xerogel load between the positive and negative electrode were evaluated $\left(\mathrm{m}_{+} / \mathrm{m}_{-}=1,1.5,2\right.$ and 3$)$, which means that the electrode density varied between a minimum value of $2.8 \mathrm{mg} \mathrm{cm}^{-2}$ and a maximum value of $8.4 \mathrm{mg} \mathrm{cm}^{-2}$ (further information about the electrode density of the electrochemical cells is presented in Table 2).

All the electrochemical measurements were performed at room temperature using a twoelectrode cell configuration (cells built with carbon xerogel-based electrodes separated by a porous paper approximately $60 \mu \mathrm{m}$ thick and graphite plate current collectors). The electrolyte used in this work was a $1.0 \mathrm{~mol} \mathrm{~L} \mathrm{~L}^{-1}$ solution of $\mathrm{Na}_{2} \mathrm{SO}_{4}$. Cyclic voltammetry (CV) and galvanostatic charge/discharge (G-CD) measurements were performed using a potenciostat/galvanostat Autolab PGSTAT 30 (Eco Chemie, BV, The Netherlands). The operating conditions included a sweep rate of $100 \mathrm{mV} \mathrm{s}^{-1}$ and a current density of $1.0 \mathrm{~A} \mathrm{~g}^{-1}$ for the $\mathrm{CV}$ and G-CD measurements, respectively, within increasing voltage windows (from 0-1.0 $\mathrm{V}$ to $0-2.0 \mathrm{~V}$, with increments of $200 \mathrm{mV}$ ). The value of specific capacitance per one electrode $\left(\mathrm{C}_{\mathrm{p}}\right)$ was obtained by $\mathrm{G}-\mathrm{CD}$ measurements and calculated by the following equation:

$$
C_{p}=C \frac{\left(m_{a}+m_{c}\right)}{m_{a} \cdot m_{c}}
$$

where $C$ is the capacitance (Farads) of the capacitor; $m_{a}$ is the mass of active material in the anode and $m_{c}$ is the weight of active material in the cathode. $\mathrm{C}_{\mathrm{p}}$ is obtained as a weighted average of the mass of active material in both electrodes, which is a more precise method to calculate the capacitance of one electrode when the masses and capacitances of two electrodes are different $[8,20]$. 


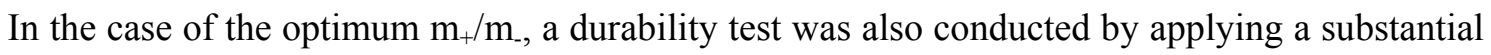
number of galvanostatic charge-discharge cycles with a voltage range from 0 to $1.8 \mathrm{~V}$ and a current density of $5 \mathrm{~A} \mathrm{~g}^{-1}$.

Impedance spectroscopy measurements were also performed on the two-electrode capacitors by using the potentiostat PGSTAT 30 equipped with a FRA2 module. The measurements were carried out in open circuit voltage (OCV) conditions using an AC potential amplitude of $10 \mathrm{mV}$ and a frequency range of $1 \mathrm{mHz}-100 \mathrm{kHz}$.

\section{Results and discussion}

The data relating to the textural and chemical properties of the carbon xerogel used as electrode material are presented in Table 1. The XER-HSA-09 sample is a micro-mesoporous material that has a very high BET surface area of almost $2900 \mathrm{~m}^{2} \mathrm{~g}^{-1}$. Moreover, as can be seen from the table, the sample has a significant mesopore volume (i.e. $V_{\text {meso }}=1.28 \mathrm{~cm}^{3} \mathrm{~g}^{-1}$ ) and the mesopore size distribution (not included in this paper) comprises mesopore diameters ranging from 2-16 $\mathrm{nm}$, pores that can favour the diffusion of the ions from the bulk of the electrolyte to the microporosity of the electrode material, especially under fast polarization conditions $[3,5,21$ 23]. In short, this carbon xerogel has textural properties that are highly suitable for the application proposed in this work.

Table 1 also summarizes the results obtained from the chemical characterization of the XER-HSA-09 xerogel. As expected, the carbon xerogel is mainly composed of C (>97 wt. \%), although a very small amount of oxygen was detected (i.e. $\mathrm{O}=2.1 \mathrm{wt}$. \%). According to these elemental analysis results, the carbon xerogel does not contain a large amount of oxygen surface groups but the limited oxygen groups presented on the surface of the electrode material have a slightly basic nature, as the value of its point of zero charge indicates (i.e. $\mathrm{PZC}=8.3$ ).

\section{Table 1}

The first electrochemical studies conducted on the carbon xerogel-based supercapacitors of different configurations were cyclic voltammetry tests (sweep rate of $100 \mathrm{mV} \mathrm{s}^{-1}$ and varying cell voltages). The voltammograms obtained from these measurements are shown in Fig. 1. As the shape of the curves of Fig. 1a evidences, the symmetric supercapacitor (i.e. when $\mathrm{m}_{+} / \mathrm{m}_{-}=1$ ) experiences problems of charge propagation at a high scan rate of $100 \mathrm{mV} \mathrm{s}^{-1}$, which are more pronounced than in the case of the asymmetric systems (i.e. when $\mathrm{m}_{+} / \mathrm{m}_{-}>1$ ). Above $1.5 \mathrm{~V}$ there is likely a slight decomposition of the electrolyte that becomes clearly apparent at $2.0 \mathrm{~V}$. 
This situation differs with the asymmetric configurations. When $\mathrm{m}_{+} / \mathrm{m}_{-}>1$, the voltammograms show quasi-rectangular shaped profiles typical of cells with an almost pure capacitive behavior, even when wide potential windows are used. When the mass ratio is set to 1.5 and 2.0 , it is possible to use operation voltage ranges up to $1.8 \mathrm{~V}$ without any detectable electrolyte decomposition or other irreversible electrode reactions. However, when $\mathrm{m}_{+} / \mathrm{m}_{-}=3$, significant humps appear during the anodic and cathodic scans, indicating that redox reaction are occurring. The humps in the voltammograms are particularly pronounced during the positive polarization above $1.5 \mathrm{~V}$, when probably the water starts to decompose and the hydrogen generated is adsorbed by the electrode material; this adsorbed hydrogen is then desorbed during the discharging step $[6,24]$. Consequently, the hydrogen produces a pseudocapacitance during the sorption/desorption process on the carbon surface, which acts as additional capacitance to the electric double layer capacitance. However, because the non- Faradaic (EDLC) and Faradaic (redox) processes have different time constants, the latter can only be observed under specific experimental conditions. Thus, when $\mathrm{m}_{+} / \mathrm{m}_{-}=3$, the negative electrode is forced to work under a high overpotential of $\sim 1.3 \mathrm{~V}$ whereas the positive electrode functions at $\sim 0.5 \mathrm{~V}$, so that the peaks showed in the voltammograms of the full capacitor are to be attributed mainly to processes that occur on the negative electrode. These preliminary results obtained by cyclic voltammetry suggest that it is possible, in certain conditions, to operate at a voltage higher than $1.23 \mathrm{~V}$, which is considered the upper limit for aqueous electrolytes due to water decomposition.

\section{Figure 1}

The characteristics of the electrodes and the electrochemical results of the carbon xerogel-based supercapacitors are reported in Table 2 . The characteristics of the cells vary according to the different mass ratios between the positive and negative electrode, since these have a noticeable influence on their electrochemical performance. Each supercapacitor (symmetric and asymmetric) was loaded with active material (micro-mesoporous carbon xerogel) ranging from 39 to $47 \mathrm{mg}$. Depending on the load of active material, the thickness and density of the carbon electrodes were slightly modified resulting in capacitances (Farad) and volumetric capacitances

$\left(\mathrm{F} \mathrm{cm}^{-3}\right)$ that changes according to the different mass ratios used. A higher capacitance as well as higher volumetric capacitance, energy and power density were reported when $m_{+} / m_{-}=1$, even though this SC is associated with a worse coulombic efficiency (i.e. the ratio between the charge discharged divided by the total charge added to replenish the charge removed) than the asymmetric SCs.

Therefore, the symmetric SC, even despite having the highest values of capacitance and energy and power density, did not exhibit the best overall electrochemical characteristics. A more 
effective comparison was obtained by considering the properties just mentioned together with the results obtained from the galvanostatic charge-discharge.

\section{Table 2}

In order to further assess the electrochemical performance of the supercapacitors, galvanostatic charge-discharge experiments at a high current load of $1 \mathrm{~A} \mathrm{~g} \mathrm{~g}^{-1}$ and in increasing voltage windows were performed (see Figure 2). The chronopotentiograms reveal that the asymmetric supercapacitors showed a better electrochemical behavior than the symmetric systems when high operating voltages were used. Up to $1.5 \mathrm{~V}$, the three asymmetric cells displayed almost symmetrical charge and discharge curves, suggesting that the electrodes possess a high capacitive performance and a good electrochemical cycle reversibility. However, when the voltage range was raised to $1.8 \mathrm{~V}$, a distortion in the linearity due to pseudo-capacitive effects was observed.

\section{Figure 2}

The progression of specific capacitance (expressed as Farads per gram of active material, considering the average mass between both electrodes) as a function of the operating voltage is shown in Fig. 3. In addition, Fig. 4 shows the coulombic efficiency values (coulombic efficiency is defined as the percentage of charge stored during the charge cycle and that recovered during the discharge cycle) obtained from the same electrochemical measurements.

\section{Figure 3}

The results in Fig. 3 reveal that there are virtually no differences between the specific capacitance values obtained in the four cases tested when the cell voltage is $1.0 \mathrm{~V}$ (C values of around $140 \mathrm{~F} \mathrm{~g}^{-1}$ ), due to the fact that the systems are operating in the region of electrochemical stability of water. As there is no extra pseudo-capacitance, the four supercapacitors are able to store the same amount of charge. However, the results obtained differ at higher operating voltages, and these discrepancies between the supercapacitors are accentuated as the cell voltage increases. It is important to note that in the case of the two larger voltage windows (i.e. $\Delta \mathrm{V}=$ 1.5 and $1.8 \mathrm{~V})$, the symmetric supercapacitor $\left(\mathrm{m}_{+} / \mathrm{m}_{-}=1\right)$ and the corresponding asymmetric cell with $\mathrm{m}_{+} / \mathrm{m}_{-}=3$ are capable of storing a greater amount of energy (i.e. 270 and $240 \mathrm{~F} \mathrm{~g}^{-1}$ when $\mathrm{m}_{+} / \mathrm{m}_{-}=1$ and 3 , respectively, compared to a capacitance of around $200 \mathrm{~F} \mathrm{~g}^{-1}$ in the case of the other two mass ratios tested). However, this higher energy storage capacitance can be attributed to a pseudocapacitance arising from redox reactions on the carbon surface, which is consistent with the results obtained from the cyclic voltammetry and charge-discharge cruves discussed in 
the previous paragraphs. Therefore, despite achieving a value of specific capacitance as high as that obtained when $\mathrm{m}_{+} / \mathrm{m}$. is set to 1 and 3 , the use of wide voltage ranges with those supercapacitors would not be possible because there is an important contribution of pseudocapacitive effects and therefore, these electrochemical systems are not stable.

\section{Figure 4}

The coulombic efficiency data collected in Fig. 4 reflect the worse electrochemical performance of the symmetric supercapacitor, $\mathrm{SC}$, when a high cell voltage was used (i.e. when $\Delta \mathrm{V}=1.8 \mathrm{~V}$, the efficiency of the SC was below $85 \%$ ). As demonstrated with Fig. 3, this supercapacitor provides a higher gravimetric capacitance than the corresponding asymmetric cells, ASCs, but this is due to redox reactions produced by water oxidation/reduction, which results in a poorer efficiency. These results demonstrate that the use of asymmetric systems with unequal loads of carbon in the electrodes is a good strategy, since it allows an increase in the operating voltage, using a cheap and environmental friendly aqueous electrolyte while ensuring at the same time a sufficiently high coulombic efficiency.

Electrochemical impedance spectroscopy measurements were performed in the frequency range of $100 \mathrm{kHz}$ to $1 \mathrm{mHz}$ on the different capacitors operating with an open circuit voltage (OCV) and unequal carbon xerogel load in the electrodes. The Nyquist plots of the SCs in Fig. 6 present typical capacitive shapes of data points distributed near a vertical line at medium and low frequency intervals. The slight inflexion from the vertical line is assigned to the resistive behaviour of real supercapacitors. The resistive effect can be imagined as the difficulty of penetration of the electric signal in smaller pores and filling of the ions (electrolyte) into the narrow carbon pores with the increasing time. An ideal electric double layer should have a quasi-instantaneous charge redistribution (electric and ionic) in the electrodes, but the porous nature of the electrodes, the ionic redistribution of cations $\left(\mathrm{Na}^{+}\right)$in the negative electrode and the anions $\left(\mathrm{SO}_{4}{ }^{2-}\right)$ in the positive electrode will occur at different time constants. To quantify the deviation from the ideal behaviour of these capacitors it is necessary to consider that the resistances range from $0.070-0.090 \mathrm{ohms}$ (at high frequency $\sim 100 \mathrm{kHz}$ ) to $10-20 \mathrm{ohm}$ (at low frequency $1 \mathrm{mHz}$ ) as a function of the characteristics of the supercapacitors. The cells loaded with $\mathrm{m}_{+} / \mathrm{m}_{-}=2$ and $\mathrm{m}_{+} / \mathrm{m}_{-}=3$ show lower resistances than those loaded with $\mathrm{m}_{+} / \mathrm{m}_{.} 1$ and 1.5 . These low resistances are mainly assigned to the small thickness of the electrodes. The electric series resistances (ESR) (high frequency region) of the cells oscillate between $0.29\left(\mathrm{~m}_{+} / \mathrm{m}_{-}=\right.$ 1.5) and $0.37 \mathrm{ohm} \mathrm{cm} \mathrm{cm}^{2}$ when $\mathrm{m}_{+} / \mathrm{m}_{-}=2$, and they are attributed to the ionic resistance of the electrolyte (which is the largest), the intrinsic resistance of the carbon electrodes and the contact resistances between the interfaces of the active material electrode/current collector. 
In a first approximation, we have estimated 70-90\% resistance as being due to the electrolyte/separator, $12-20 \%$ to the electrodes and $6-12 \%$ to the interface/current collectors. These approximate values were based on the results of a previous study [25], in which the different components of ESR were separated by studying various supercapacitors. It was shown that the ESR increased with the increase in electrode thickness according to the different carbon loads in the electrodes. The variation of the ESR of electrodes of greater thickness allowed the ionic resistance of the electrolyte to be separated from that of the carbon composite electrodes.

Deviation from the ideal capacitor (e.g. non-vertical line in the Nyquist plots) and the increase in resistance when the frequency descends from $100 \mathrm{MHz}$ to $1 \mathrm{mHz}$ does not detract from the quality of the investigated supercapacitors. As can be seen in the inset of Fig 6, the electric series resistances (ESR) (high frequency region) of the cells varied from $0.29\left(\mathrm{~m}_{+} / \mathrm{m}_{-}=1.5\right)$ to $0.37 \mathrm{ohm} \mathrm{cm}^{2}\left(\mathrm{~m}_{+} / \mathrm{m}_{-}=2\right)$. The very low values of the resistances and the high capacitances reported in this study compared favourably with previous results reported in other papers [4, 28, 29]. In fact, Stoller et al. [26] reported for graphene-based symmetric supercapacitors values of ESR resistances of $0.30,1.28$ and $1.3 \mathrm{ohm} \mathrm{cm}^{2}$ using $1 \mathrm{~mol} \mathrm{~L}^{-1} \mathrm{NaOH}, \mathrm{TEABF}_{4} / \mathrm{PC}$, and $\mathrm{TEABF}_{4} / \mathrm{AN}$ electrolytes, respectively. Their electrode thicknesses were $\sim 75 \mu \mathrm{m}$ with a cell size of $2 \mathrm{~cm}^{2}$. The same group reported for supercapacitors based on a chemical activated graphene (a-MEGO, BET SSA $\sim 3100 \mathrm{~m}^{2} \mathrm{~g}^{-1}$ ), ESR values of $3 \mathrm{ohm} \mathrm{cm}{ }^{2}$ with $1 \mathrm{~mol} \mathrm{~L}^{-1}$ $\mathrm{TEABF}_{4} / \mathrm{AN}$ electrolyte [4]. Their electrode thicknesses were of the order of 40-50 $\mu \mathrm{m}$ and the cell size was $1 \mathrm{~cm}^{2}$. The specific capacitance calculated from the discharge curves was $154 \mathrm{~F} \mathrm{~g}^{-1}$ for a current of $0.8 \mathrm{~A} \mathrm{~g} \mathrm{~g}^{-1}$ [4]. Similarly, Fic et al. [27] reported for symmetric aqueous supercapacitors $\left(\sim 0.785 \mathrm{~cm}^{2}\right.$ cell size $)$ in $1 \mathrm{~mol} \mathrm{~L}^{-1} \mathrm{Li}_{2} \mathrm{SO}_{4}$ and $\mathrm{Na}_{2} \mathrm{SO}_{4}$, specific resistance values of 0.45 and $0.55 \mathrm{ohm} \mathrm{cm} \mathrm{cm}^{2}$, respectively. They reported gravimetric capacitance values of $140 \mathrm{~F} \mathrm{~g}^{-1}$ in $\mathrm{Li}_{2} \mathrm{SO}_{4}$ and $110 \mathrm{~F} \mathrm{~g}^{-1}$ in $\mathrm{Na}_{2} \mathrm{SO}_{4}$ with activated carbon electrodes. In short, our results of $\sim 200 \mathrm{~F} \mathrm{~g}^{-1}$ for $\mathrm{m}_{+} / \mathrm{m}_{-}=2$ and $\sim 235 \mathrm{~F} \mathrm{~g}^{-1}$ for $\mathrm{m}_{+} / \mathrm{m}_{-}=3$ in $1 \mathrm{~mol} \mathrm{~L}^{-1} \mathrm{Na}_{2} \mathrm{SO}_{4}$ reported here compare favourably with the current state of the art, especially considering the low electric series resistance (ESR) of $\sim 0.3 \mathrm{ohm} \mathrm{cm}^{2}$ achieved with the asymmetric aqueous supercapcitors used in this study.

\section{Figure 5}

Table 3 provides a comparison between the electrochemical behaviour of one of the asymmetric supercapacitors prepared in this work $\left(\mathrm{m}_{+} / \mathrm{m}_{-}=2\right)$ and other asymmetric devices composed of various carbonaceous materials reported in the literature. The specific capacitance values reported in this work are greater than the literature data and this can be attributed to the nature of the active material used for the electrodes. Carbon xerogels are materials characterized by their porous properties that are highly suitable for energy storage application due to their high 
surface area $\left(\mathrm{S}_{\mathrm{BET}}\right.$ larger than a lot of commercial activated carbons) and the presence of mesopores that has a positive effect on charge storage processes since the rapid diffusion of electrolyte ions is promoted by this kind of porosity. If the specific capacitance values of $200 \mathrm{~F}$

$\mathrm{g}^{-1}$ is compared with that of $156 \mathrm{~F} \mathrm{~g}^{-1}$ obtained from Ref. [16], it can be observed that the energy storage capacitance obtained with our supercapacitor is higher although these authors also used a highly porous carbon xerogel. This may be related to the particular porous structure of the resorcinol-formaldehyde carbon xerogel used in the present work, while the active material used by the other authors was a highly microporous carbon xerogel with a low mesopore volume, which might explain its lower value of specific capacitance. According to this table, it is clear that it is possible to extend the voltage stability window using unequal mass electrodes, without the need to replace environmental friendly aqueous solutions by non-aqueous organic electrolytes or ionic liquids. Also of importance are the type of active material and the mass ratio between the positive and negative electrode used because they influence the storage capacitance and voltage range and, thereby, energy and power density values.

\section{Table 3}

The cycling performance of the XER-HSA-09 carbon xerogel-based supercapacitor $\left(\mathrm{m}_{+} / \mathrm{m}_{-}=2\right)$ collected in Fig. 7 reveals that the electrode retains $\sim 100 \%$ of specific capacitance after 4000 charge-discharge cycles $\left(\mathrm{U}=1.8 \mathrm{~V}\right.$ and a current density as high as $\left.5 \mathrm{~A} \mathrm{~g}^{-1}\right)$. Even after 2500 cycles, the specific capacitance value has been slightly increased $\left(168 \mathrm{Fg}^{-1}\right)$. These results demonstrate that the carbon xerogel-based asymmetric supercapacitor is suitable for high rate and highly stable devices.

\section{Figure 6}

\section{Conclusions}

Asymmetric supercapacitors prepared with carbon xerogel-based electrodes of different carbon loads were assembled and investigated in this work. A working voltage as high as $1.8 \mathrm{~V}$, with a good coulombic efficiency and a high energy storage capacitance, was achieved by using unequal mass carbon electrodes and a $\mathrm{Na}_{2} \mathrm{SO}_{4}$ solution $\left(1 \mathrm{~mol} \mathrm{~L}^{-1}\right)$ as electrolyte. Of the four positive/negative mass ratios evaluated $\left(\mathrm{m}_{+} / \mathrm{m}_{-}=1,1.5,2\right.$ and 3$)$, the results reveal that the optimum mass ratio is around 2 , since this cell provides a high coulombic efficiency and it operates effectively at a cell voltage of $1.8 \mathrm{~V}$ over a large number of charge-discharge cycles, without producing any appreciable electrolyte decomposition or irreversible processes in the electrodes. The specific capacitance reported for this asymmetric cell was above $200 \mathrm{~F} \mathrm{~g}^{-1}$, a 
value that is higher than those reported in the literature with similar asymmetric devices. Supercapacitors assembled with a $\mathrm{m}_{+} / \mathrm{m}_{-}=1$ and 3 display the highest values of specific capacitance. However, the results obtained from cyclic voltammetry, galvanostatic chargedischarge tests and impedance spectroscopy evidence the instability of the electrochemical cell with $\mathrm{m}_{+} / \mathrm{m}_{-}=1$ when it is operating at $1.8 \mathrm{~V}$.

On the basis of these results, it is clear that the manufacture of asymmetric supercapacitors consisting of electrodes of different mass based on a highly porous carbon xerogel is a good strategy for solving the main problem associated with supercapacitors, i.e. their low energy density compared to other energy storage devices, because higher voltage stability window in aqueous electrolytes could be used.

Acknowledgements: The authors of INCAR-CSIC would like to acknowledge the financial support provided by the Ministerio de Economía y Competitividad (Ref. MAT-2011-23733 and IPT-2012-0689-420000). The authors of CNR-ITAE acknowledge the financial support provided by Ministero dello Sviluppo Economico within the framework of "Accordo ti programma CNR-MSE", project "Sistema electtrochimici per 1'accumulo dell'energia)". The COST Organization (COST Action MP1004: Hybrid Energy Storage Devices and Systems for Mobile and Stationary Applications) is also greatefully acknowledged. E.G. Calvo also thanks Ficyt (Spain) for a predoctoral research grant.

\section{References}

[1] Kötz R, Carlen M (2000) Principles and applications of electrochemical capacitors. Electrochimica Acta 45:2483-2498

[2] Pandolfo AG, Hollenkamp AF (2006) Carbon properties and their role in supercapacitors. J. Power Sources 157:11-27

[3] Xin L, Bingqing W (2013) Supercapacitors based on nanostructured carbon. Nano Energy 2:159-173

[4] Zhu Y, Murali S, Stoller MD, Ganesh KJ, Cai W, Ferreira PJ, Pirkle R, Wallace M, Cychosz KA, Thommes DS, Stach EA, Ruoff RF (2011) Carbon-based supercapacitors produced by activation of graphene. Science 332:1537-1541

[5] Demarconnay L, Calvo EG, Timperman L, Anouti M, Lemordant D, Raymundo-Piñero E, Arenillas A, Menéndez JA, Béguin F (2013) Optimizing the performance of supercapacitors 
based on carbon electrodes and protic ionic liquids as electrolytes. Electrochimica Acta 108:361-368

[6] Frackowiak E, Abbas Q, Béguin F (2013) Carbon/carbon supercapacitors. J. Energy Chem. $22: 226-240$

[7] Lewandowski A, Olejniczak A, Galinski M, Stepniak I (2010) Performance of carboncarbon supercapacitors based on organic, aqueous and ionic liquid electrolytes. J. Power Sources 195:5814-5819

[8] Lufrano F, Staiti P, Calvo EG, Juárez-Pérez EJ, Menéndez JA, Arenillas A (2011) Carbon Xerogel and Manganeses Oxide Capacitive Materials for Advanced Supercapacitors. Int. J. Electrochem. Sci. 6:596-612

[9] Yuan A, Zhang Q (2006) A novel hybrid manganese dioxide/activated carbon supercapacitor using lithium hydroxide electrolyte. Electrochem. Commun. 8:1173-1178

[10] Wang YG, Xia YY (2005) A new concept hybrid electrochemical supercapacitor: Carbon/ $\mathrm{LiMn}_{2} \mathrm{O}_{4}$ aqueous system. Electrochem. Commun. 7:1138:1142

[11] Salinas-Torres D, Sieben JM, Lozano-Castelló D, Cazorla-Amorós D, Morallón E (2013) Asymmetric hybrid capacitors base bon activated carbon and activated carbon fibre-PANI electrodes. Electrochimica Acta 89:326-333

[12] Chu HY, Lai QY, Hao YJ, Zhao Y, Xu XY (2009) Study of electrochemical properties and the charge/discharge mechanism for $\mathrm{Li}_{4} \mathrm{Mn}_{5} \mathrm{O}_{12} / \mathrm{MnO}_{2}-\mathrm{AC}$ hybrid supercapacitor. J. Appl. Electrochem. 39:2007-2013

[13] Chae JH, Chen GZ (2012) $1.9 \mathrm{~V}$ aqueous carbon-carbon supercapacitors with unequal electrode capacitances. Electrochimica Acta 86:248-254

[14] Khomenko V, Raymundo-Piñero E, Béguin F (2010) A new type of high energy asymmetric capacitor with nanoporous carbon electrodes in aqueous electrolyte. J. Power Sources 195:4234-4241

[15] Lazzari M, Soavi F, Mastragostino M (2008) High voltage, asymmetric EDLCs based on xerogel carbon and hydrophobic IL electrolytes. J. Power Sources 178:490-496

[16] Staiti P, Arenillas A, Lufrano F, Menéndez JA (2012) High energy ultracapacitor based on carbon xerogel electrodes and sodium sulfate electrolyte. J. Power Sources 214:137-141 
[17] Arenillas A, Menéndez JA, Zubizarreta L, Calvo EG (2009) Procedimiento de obtención de xerogeles orgánicos de porosidad controlada. Patent ES 2354782

[18] Calvo EG, Juárez-Pérez EJ, Menéndez JA, Arenillas A (2011) Fast microwave-assisted synthesis of tailored mesoporous carbon xerogels. J. Colloid Interface Sci. 357:541-547

[19] Calvo EG, Lufrano F, Staiti P, Brigandì, Arenillas A, Menéndez JA (2013) Optimizing the electrochemical performance of aqueous symmetric supercapacitors based on an activated carbon xerogel. J. Power Sources 241:776-782

[20] Fang QL, Evans DA, Roberson SL, Zheng JP (2001) Ruthenium Oxide Film Electrodes Prepared at Low Temperatures for Electrochemical Capacitors. J. Electrochem. Society 148:A833-A837

[21] Frackowiak E (2007) Carbon materials for supercapacitor application. Phys. Chem. Chem. Phys 39:1774-1785

[22] Li X, Liu L, Meng Q, Cao B (2012) Synthesis and characterization of carbon aerogels doped with the anatase form of titanium oxide. J. Appl. Electrochem 42:249:254

[23] Rasines G, Lavela P, Macías C, Haro M, Ania CO, Tirado JL (2012) Electrochemical response of carbon aerogel electrodes in saline water. J. Electroanal. Chem 671:92-98

[24] Jurewicz K, Frackowiak E, Béguin F (2004) Towards the mechanism of electrochemical hydrogen storage in nanostructured carbon materials. Applied Physics A 78:981-987

[25] Lufrano F, Staiti P, Minotuli (2004) Influence of Nafion content in electrodes on performance of carbon supercapacitors. J. Electrochem. Soc. 151:A64-A68

[26] Stoller MD, Park S, Zhu Y, An J, Ruoff RS (2008) Graphene-Based Ultracapacitors. Nano Letters 8:3498-3502

[27] Fic K, Lota G, Meller M, Frackowiak E (2012) Novel insight into neutral medium as electrolyte for high-voltage supercapacitors. Energy Environ. Sci 5:5842-5850 
Table 1. Textural and chemical properties of the carbon xerogel used as electrode material

\begin{tabular}{|c|c|c|c|c|c|c|c|}
\hline \multicolumn{3}{|c|}{$\begin{array}{c}N_{2} \text { adsorption-desorption } \\
(77 \mathrm{~K})\end{array}$} & \multicolumn{4}{|c|}{$\begin{array}{l}\text { Elemental analysis } \\
\qquad\left(w t . \% d b^{c}\right)\end{array}$} & $P Z C$ \\
\hline $\begin{array}{c}\mathrm{S}_{\mathrm{BET}} \\
\left(\mathrm{m}^{2} \mathrm{~g}^{-1}\right)\end{array}$ & $\begin{array}{c}\mathrm{V}_{\text {micro }}{ }^{\mathrm{a}} \\
\left(\mathrm{cm}^{3} \mathrm{~g}^{-1}\right)\end{array}$ & $\begin{array}{c}\mathrm{V}_{\text {meso }} \mathrm{b} \\
\left(\mathrm{cm}^{3} \mathrm{~g}^{-1}\right)\end{array}$ & $\mathrm{C}$ & $\mathrm{H}$ & $\mathrm{O}$ & $\mathrm{N}$ & \multirow{2}{*}{8.3} \\
\hline 2876 & 0.97 & 1.28 & 97.5 & 0.3 & 2.1 & 0.1 & \\
\hline
\end{tabular}

${ }^{a}$ Obtained by applying the Dubinin-Raduskevich equation to the $\mathrm{N}_{2}$ adsorption isotherm

${ }^{\mathrm{b}} \mathrm{V}_{\text {meso }}=\mathrm{V}_{\mathrm{p}}-\mathrm{V}_{\text {micro }}$, where $\mathrm{V}_{\mathrm{p}}$ is the adsorbed volume at saturation point $\left(\mathrm{p} / \mathrm{p}^{\mathrm{o}}=0.99\right)$

${ }^{c}$ Dry basis 
Table 2. Characteristics of investigated electrodes and electrochemical performance for the four carbon xerogel-based asymmetric supercapacitors

\begin{tabular}{|c|c|c|c|c|c|c|c|}
\hline $\begin{array}{c}\text { Mass ratio }^{a} \\
\left(m_{+} / m_{-}\right)\end{array}$ & $\begin{array}{c}\text { Carbon } \\
\left(\mathrm{mg} \mathrm{cm}^{-2}\right)\end{array}$ & $\begin{array}{c}\text { Electrode } \\
\text { thickness }(\mu \mathrm{m})\end{array}$ & 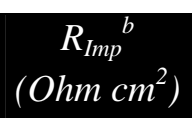 & $\begin{array}{c}\text { Farad by } \\
\text { GCD }\end{array}$ & $\mathrm{F} \mathrm{cm}^{-3}$ & $\begin{array}{c}E_{\max }^{d} \\
\left(W h k^{-1}\right)\end{array}$ & $\begin{array}{c}P_{\operatorname{maxe}} e^{-1} \\
\left(K W g^{-1}\right)\end{array}$ \\
\hline \multirow{2}{*}{1.0} & 5.14 & 210 & \multirow{2}{*}{0.34} & \multirow{2}{*}{2.64} & \multirow{2}{*}{15.0} & \multirow{2}{*}{30.0} & \multirow{2}{*}{240.6} \\
\hline & 4.76 & 180 & & & & & \\
\hline \multirow{2}{*}{1.5} & 7.12 & 230 & \multirow{2}{*}{0.29} & \multirow{2}{*}{2.40} & \multirow{2}{*}{13.0} & \multirow{2}{*}{23.7} & \multirow{2}{*}{237.1} \\
\hline & 4.74 & 180 & & & & & \\
\hline \multirow{2}{*}{2.0} & 6.46 & 220 & \multirow{2}{*}{0.37} & \multirow{2}{*}{1.79} & \multirow{2}{*}{11.5} & \multirow{2}{*}{22.8} & \multirow{2}{*}{224.6} \\
\hline & 3.34 & 120 & & & & & \\
\hline \multirow{2}{*}{3.0} & 8.40 & 240 & \multirow{2}{*}{0.31} & \multirow{2}{*}{2.02} & \multirow{2}{*}{12.6} & \multirow{2}{*}{27.1} & \multirow{2}{*}{196.5} \\
\hline & 2.80 & 110 & & & & & \\
\hline
\end{tabular}

\footnotetext{
${ }^{a}$ Mass ratio between the positive and negative electrode

${ }^{\mathrm{b}}$ Cell resistance by impedance analysis; cell size $=4 \mathrm{~cm}^{2}$

${ }^{c}$ Current density $=1 \mathrm{~A} \mathrm{~g}^{-1}$

${ }^{\mathrm{d}}$ Parameters obtained from the galvanostatic test at $1 \mathrm{~A} \mathrm{~g}^{-1}$ and $\mathrm{U}=1.8 \mathrm{~V}$
} 
Table 3. Comparison of electrochemical performance of our carbon-based asymmetric supercapacitor with literature data

\begin{tabular}{|c|c|c|c|c|c|c|}
\hline Reference & Active material & $\begin{array}{c}S_{B E T} \\
\left(m^{2} g^{-1}\right)\end{array}$ & $\begin{array}{c}R \\
\left(m_{+} / m_{-}\right)\end{array}$ & $\begin{array}{l}\text { Voltage } \\
\text { (V) }\end{array}$ & Electrolyte & $\begin{array}{c}C \\
\left(F g^{-1}\right)\end{array}$ \\
\hline This work & Carbon xerogel & 2876 & 2.0 & 1.8 & $\mathrm{Na}_{2} \mathrm{SO}_{4}$ & 200 \\
\hline [11] & $\begin{array}{l}\operatorname{AC}^{\mathrm{A}}(-) \\
\operatorname{ACF}^{-P A N I}{ }^{\mathrm{a}}(+)\end{array}$ & $\begin{array}{l}2905(-) \\
925(+)\end{array}$ & - & 1.6 & $\mathrm{H}_{2} \mathrm{SO}_{4}$ & 85 \\
\hline [13] & Cabot Monarch & 1300 & $4: 3$ & 1.9 & $\mathrm{~K}_{2} \mathrm{SO}_{4}$ & 80 \\
\hline [14] & $\begin{array}{l}\text { Norit S50 } \\
\text { oxidized }\end{array}$ & 1382 & 2.0 & $\begin{array}{l}1.5 \\
1.0\end{array}$ & $\begin{array}{c}\mathrm{H}_{2} \mathrm{SO}_{4} \\
\mathrm{KOH}\end{array}$ & $\begin{array}{l}136 \\
133\end{array}$ \\
\hline [15] & Carbon xerogel & $600^{\mathrm{b}}$ & $>1$ & $\begin{array}{l}3.4 \\
3.7\end{array}$ & $\begin{array}{c}\text { PYR }_{14} \text { TFSI } \\
\text { EMITFSI }\end{array}$ & $\begin{array}{l}26^{\mathrm{c}} \\
21^{\mathrm{c}}\end{array}$ \\
\hline [16] & Carbon xerogel & 3100 & 2.1 & 1.8 & $\mathrm{Na}_{2} \mathrm{SO}_{4}$ & 156 \\
\hline
\end{tabular}

${ }^{a}$ AC: Activated Carbon / ACF-PANI: Activated Carbon Fibers/Polyaniline

${ }^{\mathrm{b}}$ Specific surface area related to pores wider than $1.5 \mathrm{~nm}$

${ }^{\mathrm{c}}$ Specific capacitance for the global supercapacitor 


\section{Figure captions}

Figure 1.Cyclic voltammograms obtained at $100 \mathrm{mV} \mathrm{s}^{-1}$ in two-electrode cells. Mass ratio $=1$ (a), 1.5 (b), 2.0 (c) and 3.0 (d).

Figure 2. Galvanostatic charge-discharge curves measured with a current density of $1 \mathrm{~A} \mathrm{~g} \mathrm{~g}^{-1}$. $\mathrm{R}=1.0(\mathrm{a}), \mathrm{R}=1.5(\mathrm{~b}), \mathrm{R}=2.0$ (c) and $\mathrm{R}=3.0$ (d).

Figure 3. Specific capacitance vs. voltage for the asymmetric systems obtained from GCD measurements in the two-electrode cell. The cells were charged and discharged at $1 \mathrm{~A} \mathrm{~g}^{-1}$.

Figure 4. Coulombic efficiency as a function of operating voltage for the asymmetric systems evaluated.

Figure 5. Nyquist plots for two-electrode cells with the four different electrode mass ratio used. The inset shows the high frequency region of impedance.

Figure 6. Cycleability studies for the carbon xerogel-based supercapacitor when $\mathrm{m}_{+} / \mathrm{m}_{-}=2$ (voltage range: $1.8 \mathrm{~V}$; current density: $5 \mathrm{~A} \mathrm{~g}^{-1}$ ). 

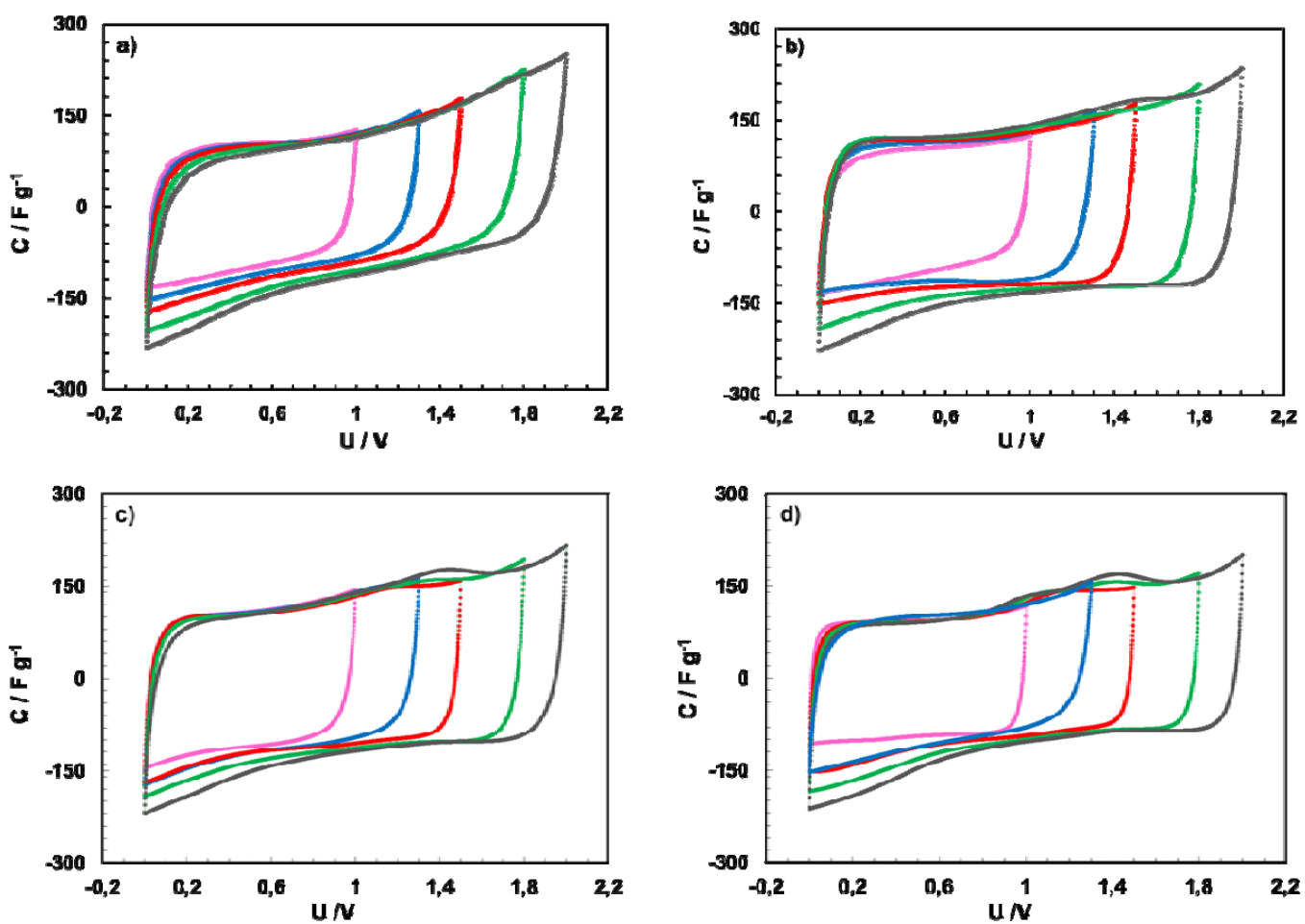

Figure 1 

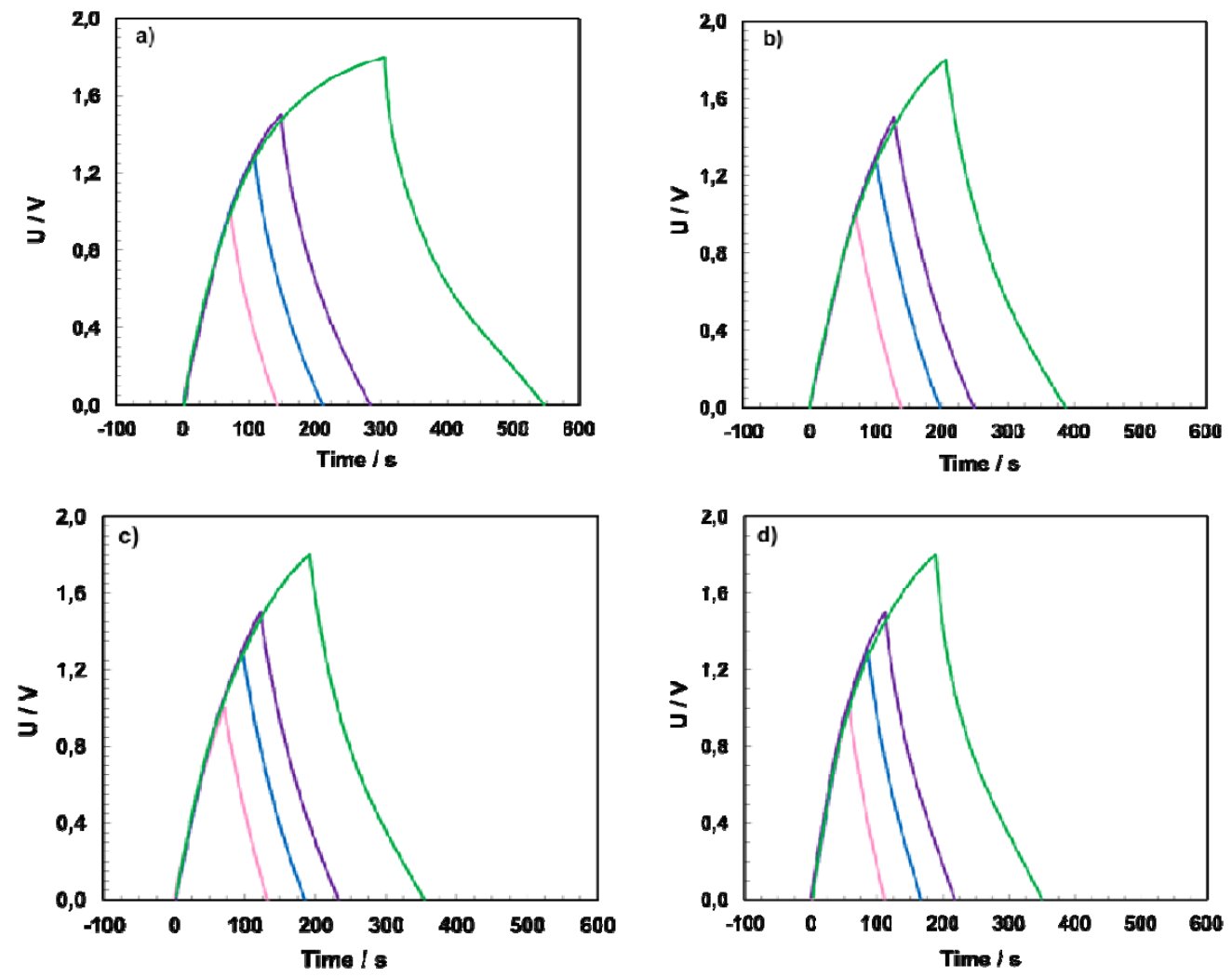

Figure 2 


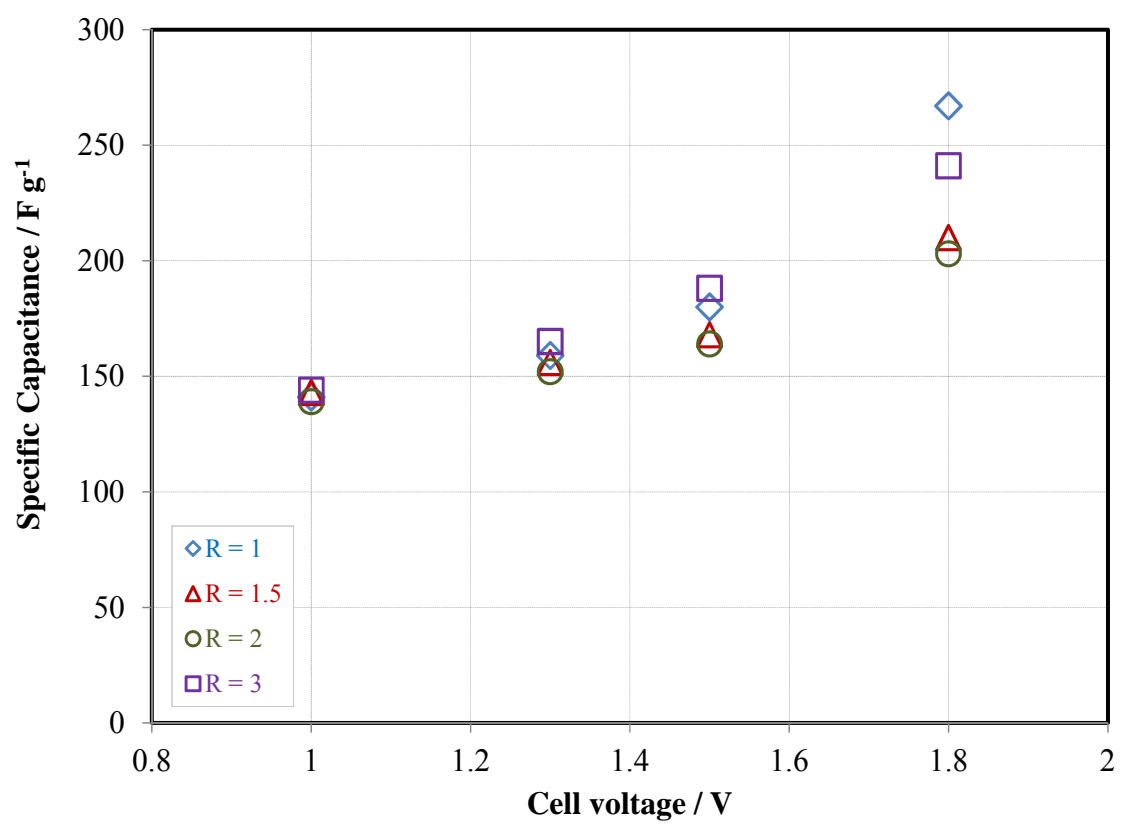

Figure 3 


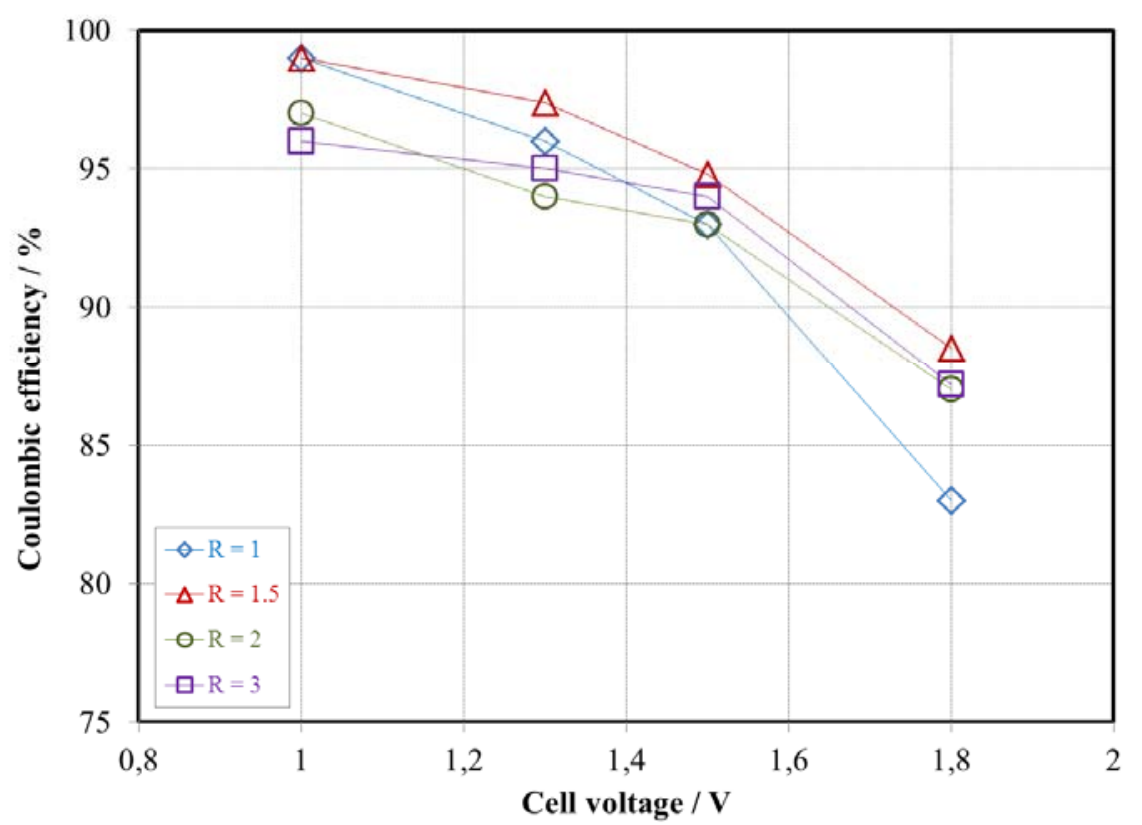

Figure 4 


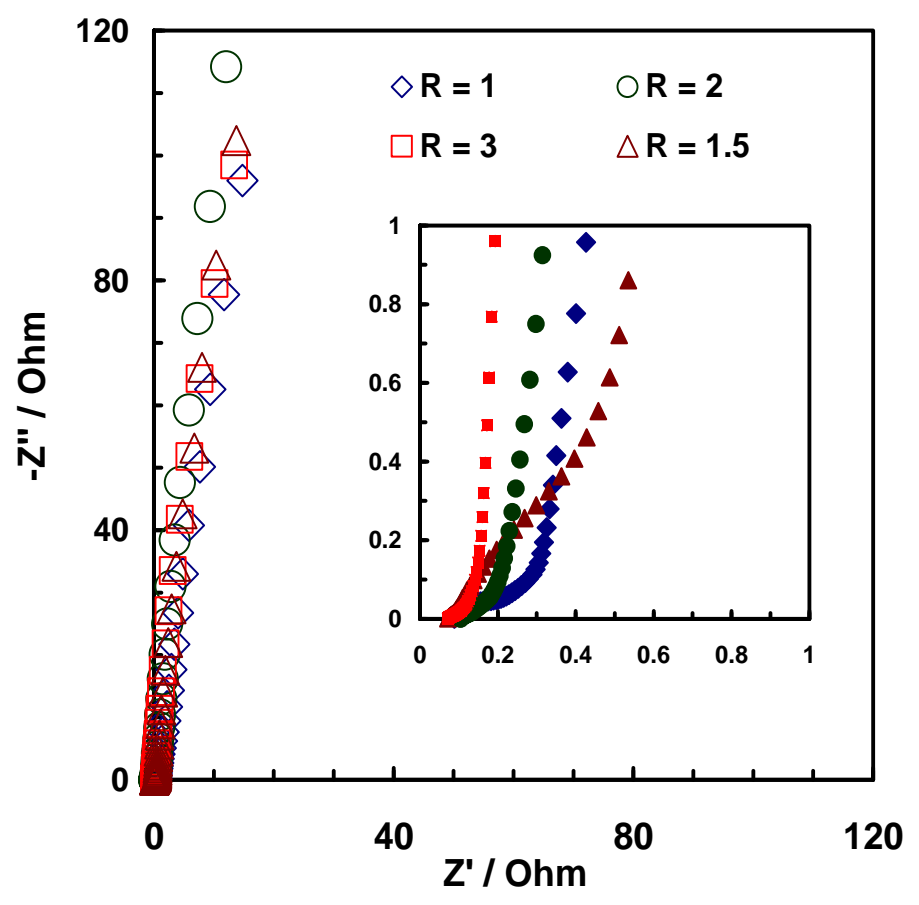

Figure 5 


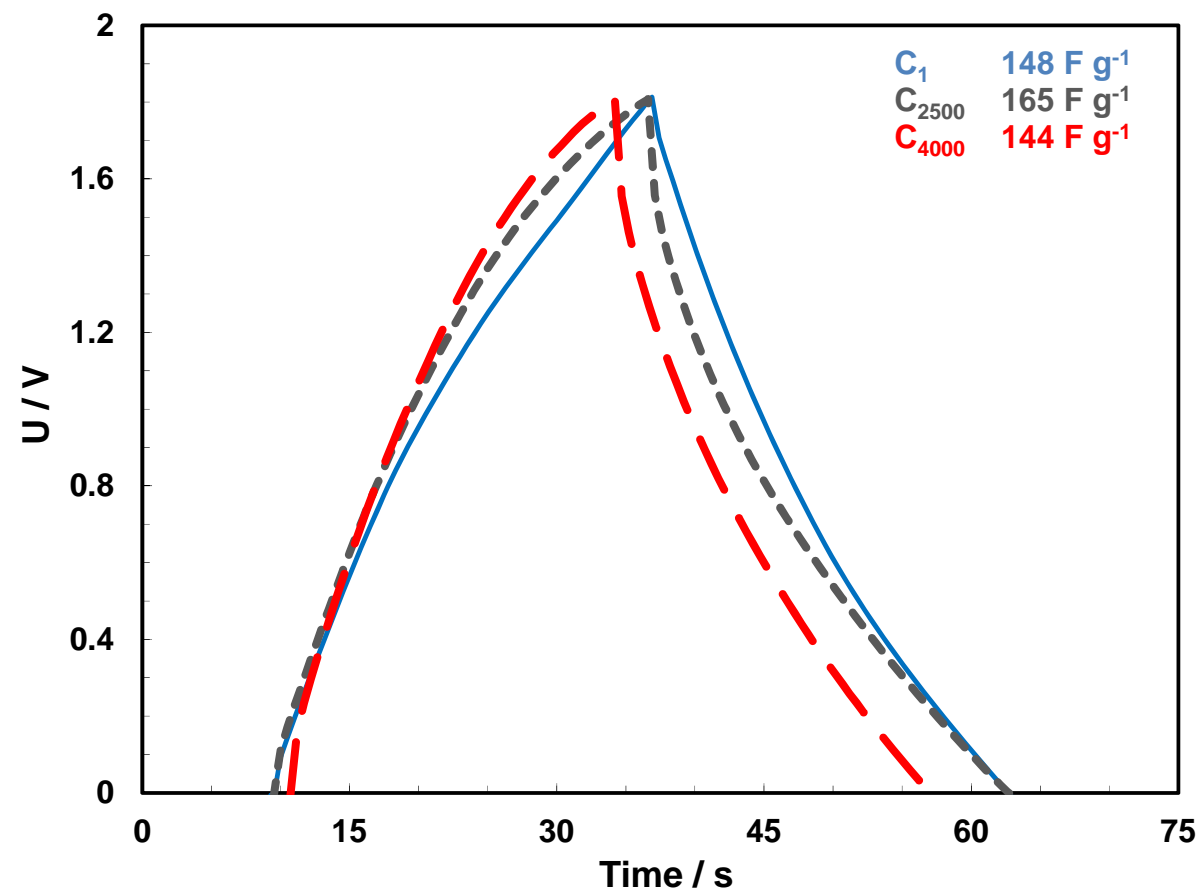

Figure 6 